\title{
Fresh, Mechanical Properties and Impact Resistance Behavior of Eco-Friend Self-Compacted Concrete
}

\author{
Sheelan M. Hama ${ }^{1}$, Alhareth M. Abdulghafor ${ }^{1}$, Mohammed T. Nawar ${ }^{2 *}$
}

\begin{abstract}
Authors affiliations:
1) Department of Civil Engineering, University of Anbar, Ramadi, Iraq
\end{abstract}

2*) Department of Dams and Water Resources Engineering, University of Anbar, Ramadi, Iraq mohammad.nawar@uoanbar.edu.iq

\section{Paper History:}

Received: $1^{\text {st }}$ June 2019

Revised: $14^{\text {th }}$ July 2019

Accepted: $17^{\text {th }}$ Sep. 2019

\begin{abstract}
In this work, waste glass powder from broken windows and plastic fibers from waste polyethylene terephthalate bottles are utilized to produce an economical self-compact concrete. Fresh properties (slump flow diameter, slump Flow T50, V. Funnel, LBox), mechanical properties (Compressive strength and Flexural strength) and impact resistance of self-compact concrete are investigated. $15 \%$ waste glass powder as a partial replacement of cement with five percentages of polyethylene terephthalate plastic waste were adopted: $0 \%$ (reference), $0.5 \%, 0.75 \%, 1 \%, 1.25 \%$ and $1.5 \%$ by volume. It seems that the flow ability of self-compact concrete decreases with the increasing of the amount of plastic fibers. The compressive strength was increased slightly with plastic fiber content up to $(0.75 \%)$, about $4.6 \%$ For more than $(0.75 \%)$ plastic fiber. The compressive strength began to decrease about $15.2 \%$. The results showed an improvement in flexural strength and an impact on the resistance in all tested specimens' content of the plastic fibers, especially at $(1.5 \%)$ fibers.
\end{abstract}

Keywords: Glass Powder; PET Plastic Fiber, Self-Compact Concrete, Fresh-Properties, Hardened Properties, Impact Resistance.

\section{Introduction}

Self-compacting concrete (SCC) can be characterized as a self-compacting concrete by its own weight without the necessity for vibration. The fine substances in SCC is higher than in normal concrete (NC). Without the vibration, the inherent risks in the process will be lower, either from insufficient or excessive vibrations, Valcuendea et al [1]. Waste glass can be used in concrete in the form of aggregates (coarse and fine) or as a powder, partially replacing cement. S. M. Hama [2] used waste plastic fibers with glass powder as a partial replacement for cement to improve properties of lightweight aggregate concrete.

Other researchers used waste glass powder to improve flexural behavior of reinforced concrete beams [3]. The effect of particle size studied by Shao et al., Chen et al and Oliveira et al. [4-6]

They found that the effectiveness of glass powder increases for finer particle led to the increasing in compressive strength and lower shrinkage. Kou and Poon [7] with Wang and Huang [8] endeavored to utilize recycled glass cullet as partial replacement of fine aggregates in SCC. The fine glass aggregates improved the flow-ability of SCC. While U and Vfunnel tests demonstrated that the time required to pass and flow through the space among steel bars increased with the increasing of the fine glass aggregate.
Sharifi et al. [9] also found that the flow ability of SCC has increased with the increasing of fine glass aggregates content. But no improvement was noted for the mechanical properties.

Matos et al. [10] investigated the ability of glass powder to improve durability of SCC. Chloride penetration and water absorption of the SCC improved by using glass powder.

Sharifi et al. [11] investigated about glass replacement as a partial replacement of cement in SCC, he used glass powder with maximum size $(100 \mu \mathrm{m})$. They found that glass powder increased flow ability of SCC with and improved strength up to $20 \%$ of glass content. Expansion of the alkali silica reaction (ASR) mortar bar for mixes with glass powder resembled the expansions of reference specimens. Hama and Hilal [12] used waste Polyethylene Terephthalate (PET) plastic as fine aggregates in SCC. They found that the increasing of plastic content decreased flow ability of SCCand a decrease in compressive strength was noticed as well.

\section{Significance of Research}

The significance of this research can be summarized in the following points:

1- Reducing the issue of waste glass and waste PET plastic bottles which leads to saving landfill space.

2- The use of little amounts of cement in concrete by replacing it with cheaper material like waste

NJES is an open access Journal with ISSN 2521-9154 and eISSN 2521-9162

This work is licensed under a Creative Commons Attribution-NonCommercial 4.0 International License 
glass powder, which is locally available, will save natural resources, reduce gas emissions from the cement industry and reduce shipping raw materials like silica fume or fly ash.

3- SCC does not need vibration which leads to saving energy.

\section{Experimental Study}

\subsection{Materials and Mix Proportional}

Portland cement (Type I) [13] was used; it has specific gravity (S.G.) of $3.16 \mathrm{~g} / \mathrm{cm}^{3}$ and fineness of $\left(376 \mathrm{~m}^{2} / \mathrm{kg}\right)$. Waste of clear glass from crushed windows was collected from wreck of building then washed and left to dry. Next it was milled to powder finer that $(45 \mu \mathrm{m})$, [see Figure 1, a]. It has specific gravity and fineness about (2.91 and 349.6 $\mathrm{m}^{2} / \mathrm{kg}$ ), respectively. The utilizing glass powder in this work has strengthened activity index about $(105 \% \geq 75 \%)$. This conformed to the requirements of ASTM C311-05 [13] for Portland cement.

The gravel was used as coarse aggregates with maximum size $(12.5 \mathrm{~mm})$, while the sand was used as fine aggregates with a maximum size $(2.36 \mathrm{~mm})$. The specific gravity for fine and coarse aggregates is (2.60 and 2.82), respectively. The mix contents, shown in Table 1, is a high-performance superplasticizer (HPSP) concrete admixture (Sika ViscoCrete-5930) which was used to get the desired workability. It complies with the (ASTM-C-494) [15] requirements for superplasticizer types $G$ and $F$.

Constant water to binder proportion of 0.35 with Cementous materials content of $500 \mathrm{~kg} / \mathrm{m}^{3}(425 \mathrm{C}+75$ glass powder) were used. The aggregates content was: $\left(850 \mathrm{~kg} / \mathrm{m}^{3}\right)$ fine aggregates and $\left(800 \mathrm{~kg} / \mathrm{m}^{3}\right)$ coarse aggregates. ( $2 \%$ HPSP) by the weight of cement were added to improve the mixes' workability. The plastic fibers with aspect ratio 28 and thickness of 0.3 were added with the mix percentage of volume: $0 \%, 0.50 \%, 0.75 \%, 1 \%$, $1.25 \%$ and $1.5 \%$ PET as shown in (Figure $1, \mathrm{~b}$ ).
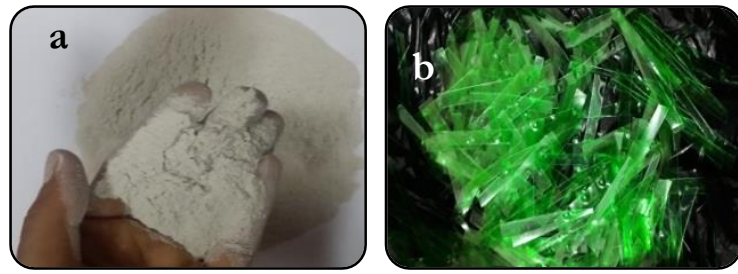

Figure (1): a- Glass powder, b- Plastic fibers

Table (1): Mixes content $\left(\mathrm{kg} / \mathrm{m}^{3}\right)$

\begin{tabular}{|c|c|c|c|c|c|c|c|}
\hline \multicolumn{7}{|c|}{$($ GP): Glass Powder \& (WPET): Waste Polyethylene Terephthalate } \\
\hline Mixes & Cement & Glass Powder & $\begin{array}{c}\text { Fine } \\
\text { Aggregates }\end{array}$ & $\begin{array}{c}\text { Coarse } \\
\text { Aggregates }\end{array}$ & Water & $\begin{array}{c}\text { SP } \\
\text { Plastic } \\
\text { fiber }\end{array}$ \\
\hline Reference & 425 & 75 & 895 & 820 & 195 & 15 & 0 \\
\hline $15 \%$ GP 0.5\% WPET & 425 & 75 & 895 & 820 & 195 & 15 & $0.5 \%$ \\
\hline $15 \%$ GP 0.75\% WPET & 425 & 75 & 895 & 820 & 195 & 15 & $0.75 \%$ \\
\hline $15 \%$ GP 1\% WPET & 425 & 75 & 895 & 820 & 195 & 15 & $1 \%$ \\
\hline $15 \%$ GP 1.25\% WPET & 425 & 75 & 895 & 820 & 195 & 15 & $1.25 \%$ \\
\hline $15 \%$ GP 1.5\% WPET & 425 & 75 & 895 & 820 & 195 & 15 & $1.5 \%$ \\
\hline
\end{tabular}

\subsection{Test Procedure}

Slump flow diameter, T50 slump flow time, Vfunnel flow time, L-box height ratio tests made according to EFNARC [16], [see Figure 2].

Additional information about mix uniformity and segregation resistance of mixes investigated from the visual observations during the T50 time test (EFNARC). Compressive and flexural strengths tests of self-compacting concrete samples carried out with respect to ASTM C39-05 [17] and ASTM C293-05 [18], respectively. Four $(250 \times 500 \times 25 \mathrm{~mm})$, slabs specimens for 10WGP, 10WGP0.5PF, 10WGP1.0PF and 10WGP1.5PF were tested under low velocity impact load. The steel ball dropped freely from height $(2500 \mathrm{~mm})$ to obtain the impact resistance. $(500 \times 250 \times 40 \mathrm{~mm})$ slabs were $(28$ days $)$ old when tested, [see Figure 3].

The test rig used for low velocity impact test consists of three main components, [see Figure 4]:

1- Steel frame: a strong and heavy steel frame which is enough to be held rigidly during the loading impact which was adopted for impact test.

2- Steel guiding pipe with an inside diameter of $100 \mathrm{~mm}$. The pipe used to drop the falling mass from a controlled height of $2500 \mathrm{~mm}$.

3- Steel ball: a steel ball of diameter $60 \mathrm{~mm}$ and mass of (1020 gm) used as a falling mass.
After curing time of 28 days, the specimens were white-painted and placed in its position in the testing frame. The falling mass dropped repeatedly, and the number of blows required casing first crack (usually observed) were recorded. The number of blows required for failure (No. of rebound) also was recorded.

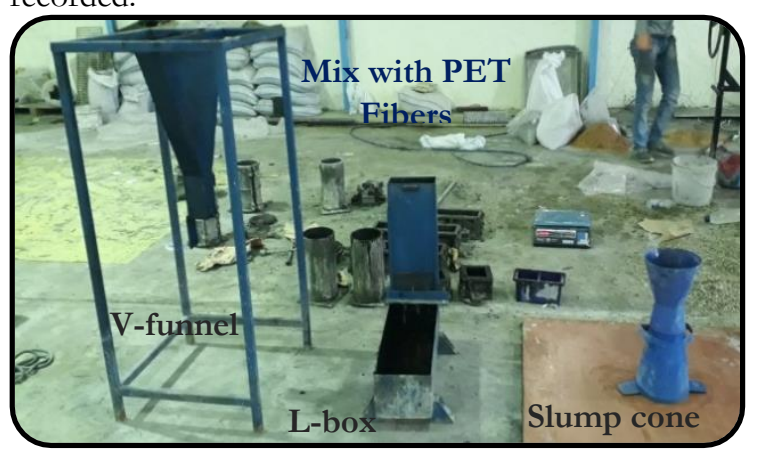

Figure (2): Preparation of instruments for SCC tests

\section{Tests Results and Discussions \\ 4.1 Fresh properties}

All mixes exhibited lower workability compared with the reference mix.

Diameters of flow for all mixes ranged between (645 to $752 \mathrm{~mm}$ ). These values are within EFNARC 
standard limits. According to EFNARC all mixes classified as SF2 class, except the mix incorporating $1.5 \%$ plastic fibers which classified as SF1, [See Figure 3].

Figure 4 illustrates variation of T50 and V-funnel Tests with percentages of GP. The T50 and V-funnel times for all SCC mixes incorporating plastic fibers increasing compared to reference mix. The reference SCC and (0.5PET,SCC) classified as VF1 for viscosity class and rest of mixes classified as VF2 for viscosity class.

L-box test made to determine blocking ratio $(\mathrm{H} 1 / \mathrm{H} 2)$ to evaluate the passing ability of the mixes. Figure 5 illustrates variation of $\mathrm{H} 1 / \mathrm{H} 2$ with percentages of GP. According to results of this work, the mixes incorporating plastic fibers up 1\% satisfied the EFNARC limitation for the given L-box height ratio and classified as PA2. Mixes with $1.25 \%$ and $1.5 \%$ PET fibers have blocking ratio $(\mathrm{H} 1 / \mathrm{H} 2)$ less than 0.8, [See Figure 6].

It seems that concrete containing plastic fibers will cause a decrease in flow speared at constant water to binder ratio which leads to increase the water demand for a given workability.

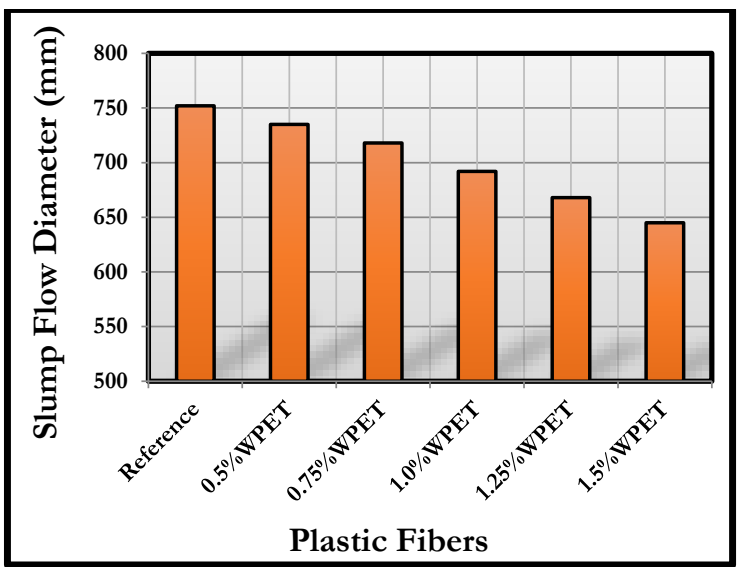

Figure (3): Slump flow diameter measurements

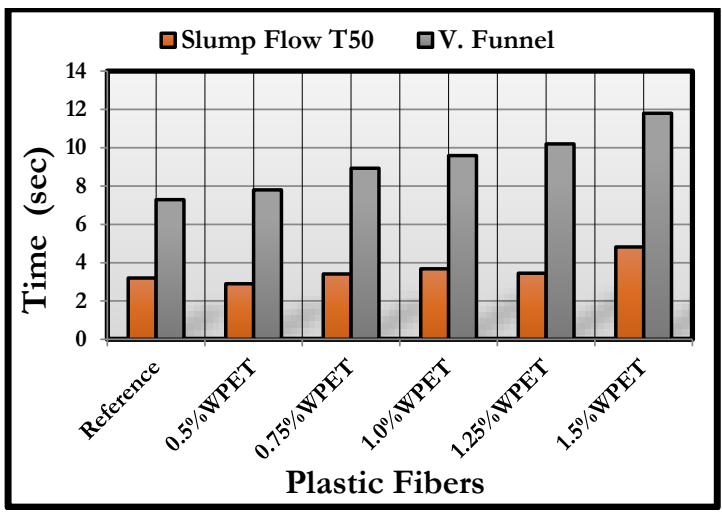

Figure (4): T50 and V. funnel time flow for mixes

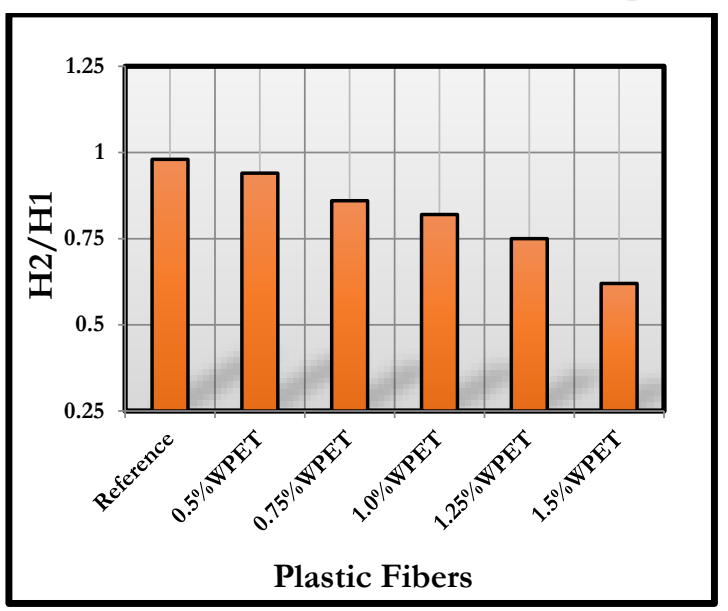

Figure (5): H2/H1 ratio for mixes

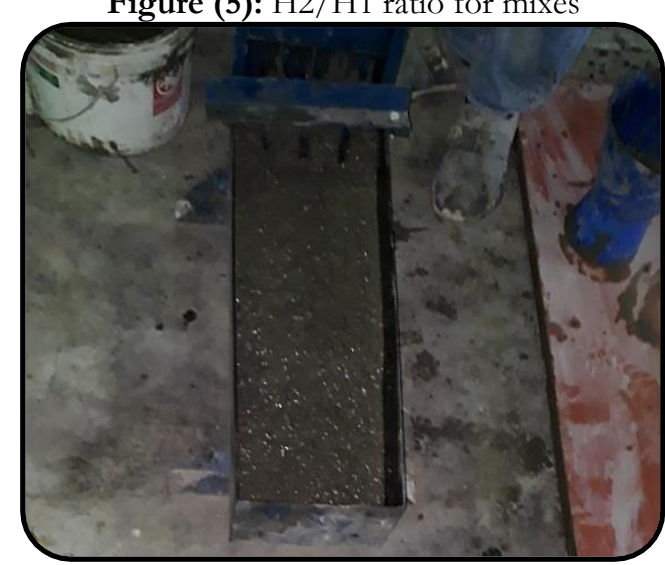

Figure (6): L-box test

\subsection{Concrete strengths}

As it's clear from results, and shown in Figure 7 , the adding of plastic fibers up to $0.75 \%$ improved slightly the strength of SCC. For higher content of fiber, the compressive strength began to decrease slightly. It seems that the fibers have no significant effect on compressive strength of SCC. Figure 8 shows the shape of failure of cubic specimens under compression load.

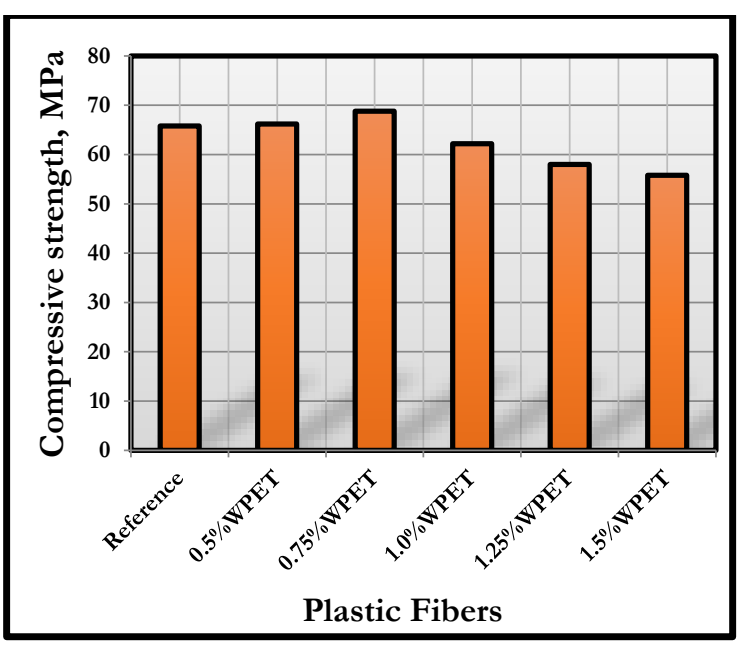

Figure (7): Compressive strength for mixes 


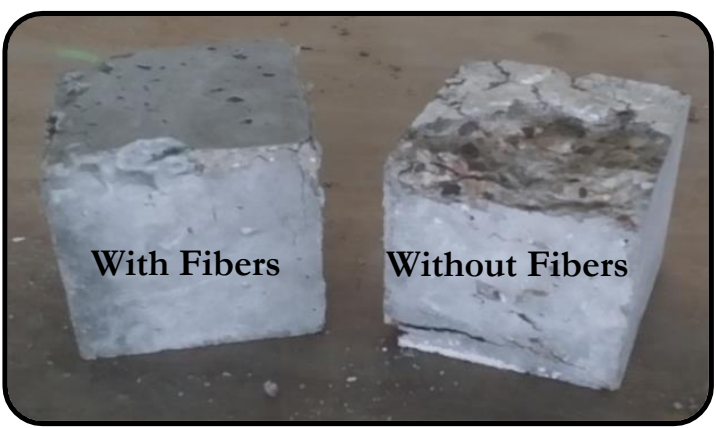

Figure (8): Shape of failure under compression load

The flexural strength effected clearly by adding plastic fibers and the increasing in flexural strength was clear as shown in Figure 9. The percentage increasing of flexural strength of (SCC- GP-WPF) concrete compared to the reference mix are $8.4 \%$, $10.3 \%, 18.5 \%, 22 \%$ and $60 \%$ for $0.5 \%, 0.75 \%, 1 \%$, 1.25 and $1.5 \%$ WPF addition, respectively. Figure 10 shows the shape of failure of prismatic specimens. The fibers bridged the cracks and prevent sadden failure. Many researchers investigated the effects of plastic on concrete properties and they found that plastic increased flexural strength scientifically $[19,20]$.

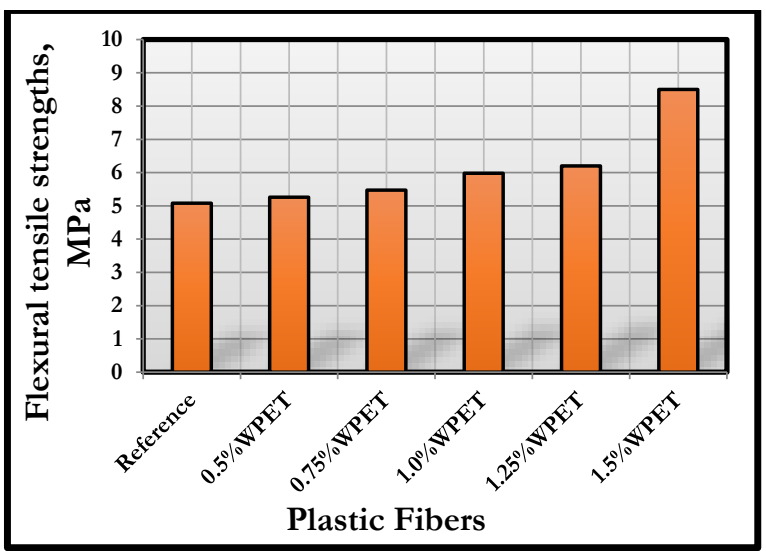

Figure (9): Flexural tensile strengths for mixes

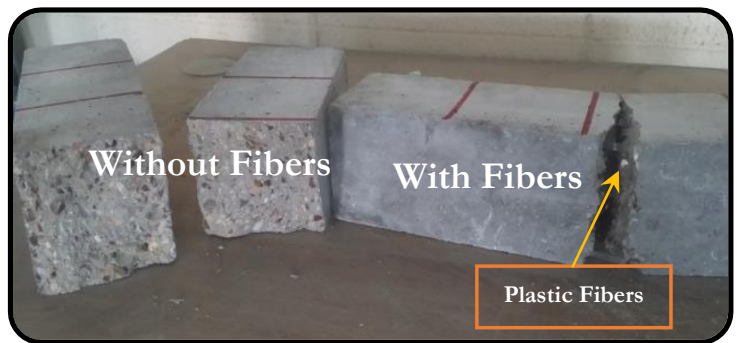

Figure (10): Shape of failure under bending

\subsection{Impact resistance of one-way SCC slabs}

The test made on prepared slabs subjected to repeat impact blows by a falling mass of (1020 gm) dropped from height $(1.5 \mathrm{~m})$, as mentioned before.

Self-compact concrete exhibited superior performance in impact resistance with increasing the plastic fiber content compared to the reference mix, the number of blows at first crack and at failure increased with the increasing of fibers amount.

This behavior is mainly ascribed to the highcapacity of plastic fiber to absorb large amount of energy prior to failure. Therefore, the energy input required for initiating the first crack and to produce failure in fiber concrete was greater than that for unreinforced concrete.

The percentage increasing in the number of blows at failure compared to the reference one was; $60 \%$, $80 \%, 200 \%, 300 \%$ and $440 \%$ for $0.5 \%, 0.75 \%, 1 \%$, 1.25 and $1.5 \%$ with WPF addition, respectively.

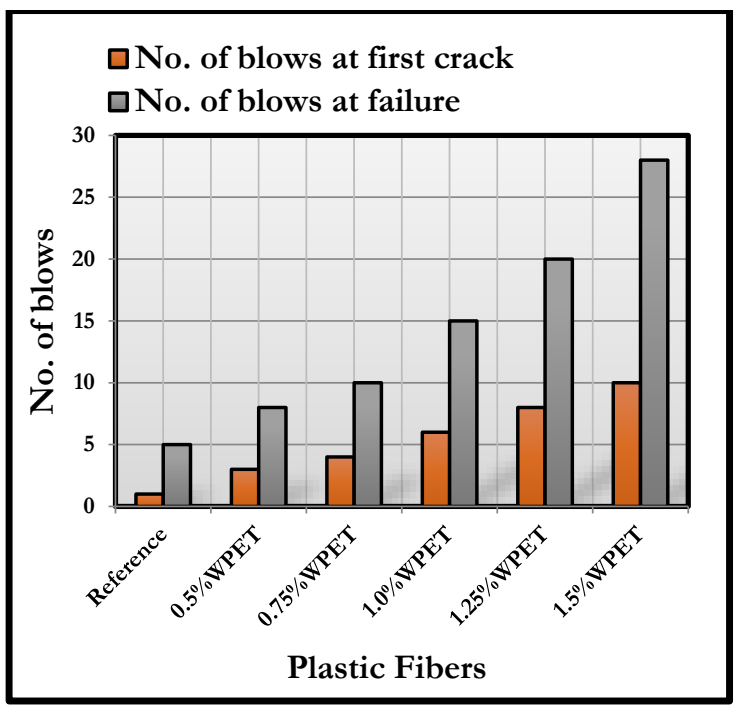

Figure (14): No. of blow at first cracks and at failure

\section{Conclusions}

Besides the reference SCC mix without fibers, five percentages of plastic fibers (by volume) were adopted: $0.5 \%, 0.75 \%, 1 \%, 1.25 \%$ and $1.50 \%$. Based on the results of this research, the following conclusions were made:

1- Using fibers decreased the workability of SCC in term of diameters of slump flow test which range between 645 to $752 \mathrm{~mm}$.

2- Plastic fibers increased both T50 and V- times. Which means the plastic fibers increased the viscosity of the mix.

3- The blocking ratio decreased with increasing the plastic fibers contents.

4- Increasing the plastic fiber content resulted in a slight increasing of the compressive strength up to $0.75 \%$ for higher fiber content, while the compressive strength began to decrease.

5- The flexural strengths increased clearly with increasing the plastic fibers contents.

6- The number of blows at first cracks and at failure increased clearly under low impact load with the increasing of plastic fibers contents.

\section{Reference}

[1] M. Valcuendea, C. Parra, E. Marco, A. Garrido, E. Martı and J. Canoves, "Influence of limestone filler and viscosity-modifying admixture on the porous structure of self-compacting concrete", Construction and Building Materials, vol. 28, pp. 122-128, 2012.

[2] S. M. Hama, "Improving the mechanical properties of lightweight porcelains aggregates concrete using different waste material", 
International Journal of Sustainable Built and Environments. vol. 6, pp.81-90, 2017.

http://dx.doi.org/10.1016/j.ijsbe.2017.03.002

[3] Sheelan M. Hama, Akram S. Mahmoud, Mohamed M. Yassen, "Flexural behavior of reinforced concrete beam incorporating waste glass powder", Structures 20 (2019) 510-518. https://doi.org/10.1016/i.istruc.2019.05.012

[4] Y. Shao, T. Lefort, S. , Moras, and D. Rodriguez, "Studies on concrete containing ground waste glass", Concrete and Cement Research, 30(1), pp. 91-100, 1999.

[5] C. H. Chen, R. W. Huang and C. C. Yang, "Waste E-glass particles used in cementitious mixtures". Cement and Concrete Research, vol. 36, pp. 449-456, 2006.

[6] L. A. Oliveira, J. P. Castro-Gomes and P. Santos, "Mechanical and durability properties of concrete with ground waste glass sand", In $11^{\text {th }}$ international conference on durability of building materials and components, Istanbul, Turkey, 2008.

[7] S.C. Kou and C. S. Poon, "Properties of selfcompacting concrete prepared with recycled glass aggregate", Cement and Concrete Composites, 31(2), pp.107-13, 2009.

[8] H. Y. Wang and W. L. Huang, "A study on the properties of fresh self consolidating glass concrete (SCGC)". Construction and Building Materials, 24(4), pp. 619-24, 2010.

[9] Y. Sharifi, I. Afshoon and Z. Firoozjaie, "Fresh properties of self-compacting concrete containing ground waste glass micro-particles as cementing material", Journal of Advanced Concrete Technology, 13(2), pp. 50-66, 2015.

[10] A. M. Matos, T. Ramos, S. Nunes and J. S. Coutinho, "Durability Enhancement Of SCC With Waste Glass Powder", Materials Research, 19(1), pp. 67-74, 2016.

[11] Y. Sharifi, I. Afshoon, Z. Firoozjaie and P. Momeni, "Utilization of Waste Glass Micro-particles in Producing Self-Consolidating Concrete Mixtures",
International Journal of Concrete Structures and Materials.10 (3), pp. 337-353, 2016.

[12] S. M. Hama, and N. N. Hilal, "Fresh properties of self-compacting concrete with plastic waste as partial replacement of sand", International Journal of Sustainable Built and Environment. vol. 6, pp. 299308, 2017.

http://dx.doi.org/10.1016/j.ijsbe.2017.01.001

[13] Iraqi Specification No. 5, Portland cement. "The Cement Agency for Standardization and Quality Control", Baghdad, 1984.

[14] ASTM: C311, "Standard Test Methods for Sampling and Testing Fly Ash or Natural Pozzolans for Use in Portland-Cement Concrete", American Society of Testing and Material International, 2005.

[15] ASTM: C494, "Chemical Admixtures for Concrete", American Society of Testing and Material International, 2005.

[16] EFNARC, "Specification and guidelines for selfcompacting concrete", Free pdf copy downloadable from, 2005.

http://www.efnarc.org/pdf/SandGforSCC.PDF [17] ASTM: C39, "Compressive Strength of Cylindrical Concrete Specimens", American Society of Testing and Material International, 2005.

[18] ASTM: C293, "Flexural Strength of Concrete (Using Simple Beam with Center-Point Loading)", American Society of Testing and Material International, 2005.

[19] Abdulkader I. Al-Hadithi and Sheelan M. Hama 2009. Some Mechanical Properties of Polymer Modified Concrete Rreinforced with a Waste Plastic Fiber. The Iraqi Journal For Mechanical And Material Engineering, Special Issue (D), pp. 653-664.

[20] Khalil I. Aziz, Sheelan M. Hama, Huda M. Kuhair " Effeciency of Waste Plastic Fiber on Behavior of Composite Steel Plate-Concrete Push Out Test" 11th International Conference on Developments in eSystems Engineering (DeSE). (2018) pp.335-339. DOI:10.1109/DeSE.2018.00066 